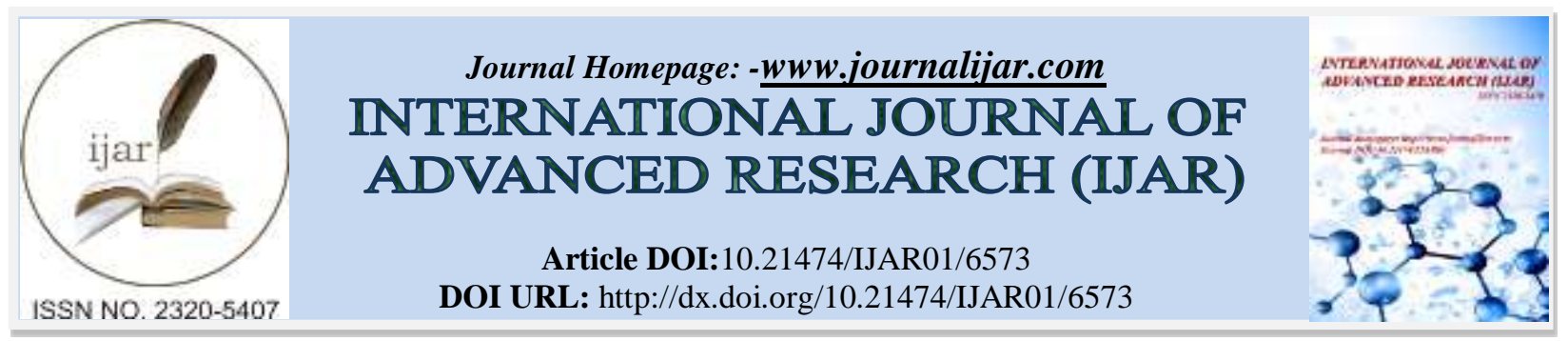

RESEARCH ARTICLE

\title{
EFFECTS OF CO-ORDINATION STRATEGIES ON EFFICACY IN THE ADMINISTRATION OF FINANCES IN EARLY CHILDHOOD DEVELOPMENT CENTRES IN UASIN-GISHU COUNTY, KENYA.
}

Jane Jelimo Michael.

Kisii University, Eldoret Campus P.o box 6434 Eldoret Kenya.

\section{Manuscript Info}

Manuscript History

Received: 18 December 2017

Final Accepted: 20 January 2018

Published: February 2018

Keywords:-

Co-ordination, Strategy, Efficacy,

Administration, Finances, ECD.

\begin{abstract}
Early childhood education is the basis upon which all levels of education are anchored. The main purpose of this study was to assess co-ordination as a management strategy and its effects on efficacies in the administration of finances in public ECDE centers in Uasin-Gishu County, Kenya. The study adopted a descriptive survey research design. The sample size was based on Krejcie and Morgan formula. Schools were stratified to their quotas. Furthermore, 224 ECDE teachers, 55 headteachers, 55 SMC chairpersons, 1 QASO, 1 County chief education officer and 1 County auditor were sampled using stratified, simple random sampling and purposive sampling techniques. Data was collected using interviews and questionnaires. The instruments were piloted in Nandi County and Cronbach Alpha coefficient was used to test the reliability of the instruments. Data was analyzed using frequencies, percentages, and Pearson Correlation Coefficient analysis. This study found out that Infrastructural development funds for ECDE schools in the county were mainly from the County government and parents. In addition, the study found a significant correlation between coordination strategies and financial management efficacies. The study recommends that there is need for ECDE management committee to: plan for resources early enough before spending to curb waste. It is hoped that the findings will be of great significance to policy makers on understanding the best strategies which if implemented will promote efficacies in the administration of ECDE funds.
\end{abstract}

Copy Right, IJAR, 2018,. All rights reserved.

\section{Introduction:-}

According to Briggs and Ayot (1988), a cornerstone of improving the socio-economic and welfare of the people and the society at large is through education. Education training investment has assured higher individual earnings than investing in alternative segments of the financial system (Woodhall \& Psacharapoulos, 1985 and World Bank, 2008). Furthermore, Maryor et al (2005) stated that schooling is considered as the foundation of Human, Cultural, Social, and Monetary capital and is considered as valid in terms of both character and collective excellent, ensuing into explosive increase each in countrywide and international area. In addition, KIPPRA (2008) found that establishment of first-rate training is crucial in producing the chances and advantages of social and monetary advancement. 
In Sub-Saharan Africa, the problem associated with the provision of adequate early childhood education is huge infrastructural facilities. An estimated cost of up to US\$ 30 billion is needed to build upto 10 million classrooms (World Bank, 2013). In Nigeria, several matters threaten efficacies in management of classroom and toilet construction and maintenance. The major setback in public ECDE centres is that management issues have not been streamlined in the policy document (2006). That public ECDE centres do not have independent headteachers and those available are on acting capacity and are under the headteachers of the hosting public primary school hence cannot make independent decisions without consulting the hosting headteacher and the ECDE management committees who have little knowledge and skills on financial management (World Bank, 2010).

World Bank report (2010) indicate that most public ECDE centres in Kenya have stalled programmes marked by irregular and delay of teachers' salaries, inconsistent feeding programmes, poor infrastructure and unclear policy guidelines. Several studies on the efficiency of management of secondary funds and primary have been conducted (Owiti, 2010; Okumu, 2014; Jane, Rotich \& Kiprop, 2014). Although these studies have addressed the implementation and challenges affecting financial management in secondary and primary school sections, they have not addressed the effects of management strategies on efficacies in financial administration in public ECDE centres, an issue which this study sought to look at.

\section{Literature Review:-}

According to Allis, (2004), financial resources are crucial institutional resources since no institution can thrive without adequate financial resources. It is therefore imperative for institutions, firms, organizations and business entities to consider financial management so as to enhance their performance and more so mitigate exposure to financial risks. According to Fung (2015) the rationale for financial management is raising funds for both short-term and long-term use and enhancing proper utilization of the funds.

The finances for learning institutions are used for daily operations and activities of concerned institutions. In the case of secondary schools, the principals and administrators are charged with the responsibility of planning the school budget in order to achieve the objectives of the school and more so effective financial administration (Sharma, 2011). A lot of countries have therefore devolved the administration of financial inputs to schools in a bid to enhance their administrative efficacies. This was eminent in a study carried out in France (Crouch \& Winker, 2008). Nevertheless, despite the essence placed on financial resources in bringing about the much-needed change and delivery of services, it is noted sometimes the resource is misused and misappropriated by school board of management (Rosen \& Gayer, 2010).

In Kenya financing ECDE programmes should be done either through efficient use of existing health, infrastructure, nutrition, and basic education programmes and by mobilizing additional community resources (UNESCO, 2005). Nevertheless, ECDE would not be complete without the mention of the vital programmes incorporated in it. There is need to take into account the roles they play in actualizing the realization of ECDE as follows:

A study by Owiye (2010) on management of resources in pre-school centres and its implications on quality also revealed that there were variations in financial administration, provision of infrastructure and teaching/learning resources depending on sponsor, locality and type of the centre. Results also indicated that teacher remuneration was poor and they lacked opportunities for professional advancement (development). The study recommended that preschool teachers be provided with the right environment which is essential for effective and efficient teaching aimed at promoting the use of resources for holistic development of learners.

In a study by Sitati, Bota and Ndirangu (2014) most ECDE centres in Kenya have implemented the feeding program. The results reflect a great effort made by the ECE stakeholders to ensure the nutritional needs of children are met at the institutions. Of great concern is the realization that early age of the child's development and learning process is affected by the nutritional care given to it.

Discrepancies of payments are wanting especially with the variation on payment where the County subsidizes ten thousand shillings per month as salary for one or two teachers whereas the parents or the sponsor pays as low as two thousand to four thousand to the other teachers yet the workload is the same. The worst scenarios are cases where teachers' salaries are delayed for months forcing others to opt for voluntary services in cases of extreme poverty (Elimu-Yetu coalition, 2013). To a large extent and most commonly, Early Childhood Education teachers' salaries 
average KSh. 2,000 per month, with large variations between the rural, urban and slum pre-schools (UNESCO, 2005).

A study by Zyl, (2010) pointed out that there is a relationship between labour productivity and remuneration. There are other issues in Kenya which are varied and revolve around the provision of vital resources and services which range from unclear policy guidelines on management of ECDE programmes, lack of sufficient trained personnel, limited finances, poor or inadequate infrastructure, political interference to adverse effect of Free Primary Education (FPE) on ECDE education (World Bank, 2010). However, this study assessed management strategies and its implications on co-ordination of finances in public ECDE centres in Uasin-Gishu County.

\section{Methodology:-}

\section{Research Design:-}

Research design according to Creswell (2009) is a plan and the procedure for research that extent the decisions from broad expectations to detailed approaches of data collection and analysis. The current study adopted a descriptive survey design. Descriptive surveys allow rapid collection of data from a large sample within the shortest time possible by use of questionnaires, interview schedules and document analysis. In addition, the study adopted convergent mixed methods using pragmatist paradigm for it was considered to be useful in helping researcher meet the criteria for estimating the goodness of their answers in better way as compared to those of single strategy designs (Tashakkori \&Teddlie, 2003).

\section{Target Population:-}

Population denotes the entire group of subjects including the entire number of environments which are considered to be of concern to the investigator (Oso \& Onen 2008). The research targeted all public ECDE centres in Uasin-Gishu County. The region has 576 public ECDE centres. All the 1728 ECDE teachers, 422 headteachers and 422 SMC chairpersons, 1 County quality assurance and standards officer, 1 County chief education officer and 1 County auditor form the study population of 2575 .

\section{Sample Size:-}

A total of 2572 respondents consisting of 1728 ECDE, 422 head teachers and 422 SMC chairpersons were used to get a sample size for the research. This research was based on a sample size determination formula advanced by Krejcie and Morgan (1970) as cited by Kasomo (2001). The total sample size for the study is indicated in Table 1.

Table 1:- The Sample Size for Respondents

\begin{tabular}{|l|c|c|}
\hline Category & Target population & Sample size \\
\hline ECDE Teachers & 1728 & 224 \\
\hline Headteachers & 422 & 55 \\
\hline SMC Chairpersons & 422 & 55 \\
\hline County Quality Assurance Officer & 1 & 1 \\
\hline County ECDE director & 1 & 1 \\
Auditor & 1 & 1 \\
\hline Total & 2575 & 337 \\
\hline
\end{tabular}

\section{Sampling Techniques:-}

In selecting ECDE centres included in this research, stratification was used to place ECDE centres in their quotas; Kesses sub-county 35, Kapseret Sub-County 28, Ainabkoi Sub-county 26, Moiben Sub-County 30, Turbo Subcounty 48 and Soy Sub-County 64 totaling to 231 ECDE centres. Stratification guaranteed that each individual stratum was assigned the proportionate number of ECDE centres as in the population.

Pre-schools which were placed in each stratum were randomly carefully chosen by using specific codes to identify them. The researcher assigned a unique code to each ECDE centre for identity. Stratified simple random sampling was also used to select ECDE centres to participate in the study. stratification guaranteed that each ECDE centre in each stratum had an equal chance to be included in the sample. The QASO, the County chief education officer, Headteachers, SMC chairpersons and the County auditor were purposively sampled. 
Moreover, 224 ECDE teachers were chosen through the adoption of simple random sampling procedure. This procedure ensured that all the members of the population are given an equal chance of being included in the sample. The outcomes attained from the use of probability or random sampling procedures can be assured in terms of likelihood for instance errors of estimation or the significance of outcomes obtained from a random sample can be measured. This circumstance brings out the advantage of random sampling strategy over the purposive sampling strategy (Kothari, 2008).

\section{Research Instruments:-}

Researchers like Kombo and Tromp (2006) posit that in social science, interviews questionnaires, observation checklists and standardized evaluations are commonly used as research tools. Structured interview was administered to County Quality assurance and standards officer, the County chief education officer and the County auditor in order to understand better issues of financial administration efficacy in public ECDE centres. A great deal of qualitative is obtained from talking with individuals either through formal interviews or through casual conversations. Questionnaire was the main tool used to gather research information from the primary school head teachers, SMC chairpersons and ECDE teachers. Kothari (2008), postulated that questionnaires are normally free from the interview predisposition as the answers from the respondents are in respondents' own words. In addition, research participants also have sufficient time to give well thought out answers.

\section{Validity and Reliability of the Research Instruments:-}

Validity according to Kothari (2008) is the correctness, accuracy, meaningfulness of implications and dependability of outcomes of conclusion, which are based on the research findings. The researcher sought expert views on both content and construct validity of the research instruments. Comments besought from them were used to enhance the study's instrument before beginning on data collection procedures.

To determine the reliability of the instruments, teachers' questionnaires and SMC chairpersons were piloted using 30 public ECDE teachers and SMC chairpersons in Nandi County who were not part of this research study. The testretest strategy was adopted to test the reliability of questionnaires. The Pearson's Product Moment Correlation (r) was used to calculate the reliability coefficient between the first and second scores. The coefficient attained was then transformed into a suitable correlation for the entire test by use of the Spearman and Brown prophecy formula. A correlation coefficient of (r) 0.75 or more was considered appropriate to establish the reliability of the research instruments as indicated by Orodho (2009). In this research, a correlation coefficient of 0.78 was attained showing that the tools were dependable and therefore were deemed fit for collection of data.

\section{Data Analysis:-}

Analysis of data involves interpretation, organization and presentation of collected information so as to decrease the information collected from the field to be practical (Onen \& Oso, 2005). Data obtained was analyzed using quantitative and qualitative techniques. The quantitative data from the questionnaire were first subjected to preliminary processing through validation, coding and tabulation in readiness for analysis with the help of the statistical package for social science (SPSS) computer package as a 'toolbox' to analyze data related to objectives. Frequencies, percentages, mean and Standard deviation was used to analyze quantitative data. Pearson Correlation Coefficient was employed to determine relationship that exists between the independent (planning,) variable and dependent variable (financial efficacies). Qualitative data from interview schedules was transcribed, thematically classified and arranged before they were reported in narrations and quotations.

\section{Ethical Considerations:-}

Hesse-Biber \& Leavey, (2007) notes that participants in research are required to versed with ethical requirements in order to safeguard information obtained from their respondents. Before commencing on collecting data, the investigator required a research permit from the National Commission for Science, Technology and Innovations (NACOSTI). In addition, permission was sought from County Director of Education and head teachers of the selected primary schools which houses the ECDE centres before conducting the study. The respondents' involvement in the study was voluntary and free. There was no promise of benefits for involvement in the study and the respondents were asked to sign the informed consent form. The participants were further guaranteed that information given would be treated private and confidential as it was meant for this study only. In addition, the participants were also informed that they were free to withdraw from the study at any time they deem fit. 


\section{Study findings:-}

The aim of this research was to examine co-ordination strategies and its effects on efficacy in the administration of finances in public ECDE centres in Uasin-Gishu County. To attain this objective, first the participants were requested to rank their degree of disagreement or agreement on a likert scale questions on co-ordination strategies employed in various ECDE centres and its effects on efficacy in the administration of finances. Their responses were tabulated and the outcomes of the analyzed data are shown in Table 2.

Table 1:- Responses on Co-ordination Strategies and Efficacy in the Administration of Finances

\begin{tabular}{|l|l|l|l|l|l|l|}
\hline \multirow{2}{*}{ Statement } & $\mathrm{D}$ & \multicolumn{2}{l}{ UD } & $\mathrm{A}$ \\
\cline { 2 - 7 } & $\mathrm{F}$ & $\%$ & $\mathrm{~F}$ & $\%$ & $\mathrm{~F}$ & $\%$ \\
\hline $\begin{array}{l}\text { Infrastructure development funds mainly come from } \\
\text { Government and parents' contribution }\end{array}$ & 51 & 16.5 & 41 & 13.3 & 217 & 70.2 \\
\hline $\begin{array}{l}\text { Parents buy for their children school uniform and some } \\
\text { stationery. }\end{array}$ & 13 & 4.2 & 9 & 2.9 & 287 & 92.9 \\
\hline $\begin{array}{l}\text { Pre-school lack basic physical infrastructure, like drinking } \\
\text { water, toilets, buildings and classrooms due to inadequate } \\
\text { funding. }\end{array}$ & 60 & 19.4 & 26 & 8.4 & 223 & 72.2 \\
\hline $\begin{array}{l}\text { Pre-school teacher remuneration is poor as it depends largely } \\
\text { on availability of parental contributions }\end{array}$ & 70 & 22.6 & 7 & 2.2 & 232 & 75 \\
\hline $\begin{array}{l}\text { There is lack of opportunities for professional development } \\
\text { of pre-school teachers due to inadequate funding. }\end{array}$ & 69 & 22.3 & 26 & 8.4 & 214 & 69.3 \\
\hline $\begin{array}{l}\text { The provision of finances by the county government has } \\
\text { enabled the acquisition of learning materials and resources in } \\
\text { ECDE centres. }\end{array}$ & 260 & 84.1 & 0 & 0.0 & 49 & 15.9 \\
\hline $\begin{array}{l}\text { The government has introduced grants to provide free meals } \\
\text { to learners in ECDE centres to cater for the nutritional needs } \\
\text { of disadvantaged learners. }\end{array}$ & 219 & 70.9 & 13 & 4.2 & 77 & 24.9 \\
\hline $\begin{array}{l}\text { Payment of teachers' salaries has been hampered by the } \\
\text { effect of Free Primary Education (FPE). }\end{array}$ & 51 & 16.5 & 34 & 11.0 & 224 & 72.5 \\
\hline
\end{tabular}

Table 2 shows that $217(70.2 \%)$ respondents agreed with the statement that infrastructure development funds mainly come from Government and parents' contribution, 51(16.5\%) respondents were in disagreement with the view and $41(13.3 \%)$ respondents were not decided on the view. The study findings showed that majority $(70.2 \%)$ of the ECDE teachers and SMC committee members in Uasin Gishu County believed that infrastructural development funds for ECDE schools in the county were mainly from government and parents. This is attributed to the fact that ECDE school infrastructure development is mainly undertaken by parents and to a small extent the county government. The ECDE section as per the New Constitution (2010) is a fully devolved function and therefore infrastructural development is mainly supported by the county governments. However, parents contribute a lot for the general development of the schools. In some instances, other educational stakeholders such as NGO and churches sponsor the infrastructural development in ECDE centres. The study findings were consistent with those of Motuka and Orodho (2014) and Getange, et al., (2014) which showed that financing of infrastructure in public schools and ECDE centres mainly came from Government and parents' contributions in cash and in kind, and selfhelp (harambee drives); schools' own income generating activities.

Further, 287(92.9\%) respondents agreed with the statement that parents buy for their children school uniform and some stationery, and $13(4.2 \%)$ respondents were in disagreement with the statement while $9(2.9 \%)$ respondents were undecided on the statement. It emerged from the responses that a majority (92.9\%) respondents reported that ECDE parents bought for their children school uniform and stationery. This is attributed to the fact that the government partly provides for infrastructure and instructional materials leaving the rest to be taken care of by parents. This implies that ECDE parents are overburdened with buying writing materials and school uniform despite paying school fees for their children. When this is the case, children from low economic backgrounds will suffer most as they will be on and out of school due to fees problems while those from very poor families may be denied access to education as they may not afford. This is in agreement with the World Bank report (2004) which revealed that user charges were a major hindrance to the provision of universal education in third world countries. 
In Kenya financing ECDE programmes has to be done either through efficient use of existing basic education programmes (county governments) and mobilizing additional community resources and also involving parents to pay fees and buy stationary to their children, (UNESCO, 2005). This is in agreement with WHO, (2013) report which showed that ECDE programmes and systems of support are seriously underfunded when this is the case children from low economic backgrounds suffer most as they may be forced to drop from school because they cannot afford to sponsor themselves.

Similarly, 223(72.2\%) respondents agreed with the statement that their pre-schools lacked basic physical infrastructure, like drinking water, toilets, buildings and classrooms due to inadequate funding, 26(8.4\%) respondents were not decided on the view while 60(219.4\%) participants disagreed with the statement. From the outcomes, it was found out that a majority (72.2\%) of the teachers and SMC chairpersons cited that their pre-schools lacked basic physical infrastructure, like drinking water, toilets, buildings and classrooms and this was attributed to inadequate funding by the government, low economic ability of parents to support ECDE programmes, inconsistent funding by donors and unclear policies in the management of ECDE programmes. This implies that most ECDE centres in Uasin-Gishu County lacked basic infrastructure and therefore the county government need to put into consideration the funding of infrastructure in ECDE centres. This implies that most learners are placed at risk given that they are within the bracket of below 5 years whose immunity is still low to cope with harsh learning environments where classrooms' doors and windows are open, floors are dusty/uncemented hence frequent colds and flues. When this happens, learners will skip classes as they recuperate from illnesses. This also supports the findings of Mohammed (2011) which indicate that in Punjab province of Pakistan, all schools lacked basic physical infrastructure like drinking water, toilets, buildings and classrooms due to inadequate funding to cater for the infrastructural development.

In addition, 232(75.0\%) respondents agreed with the statement that pre-school teacher remuneration is poor as it depends largely on availability of parental contributions, 70(22.6\%) respondents disagreed while 7(2.2\%) participants were not decided on the view. The study findings showed that majority (75.0\%) of the teachers and SMC chairpersons reported that teacher remunerations was poor and this was attributed to the fact that employment of teachers is vested in the hands of parents who have other responsibilities and may not be able to remunerate attractively.

Besides, salaries for teachers paid by parents, is not guaranteed each month as it depends on collections from school fees forcing some teachers to go for months without pay while others opt to provide voluntary services. This in itself is demoralizing to the service providers hence compromises on quality of services. This could be attributed to unclear policy on issues of management of ECDE Education in addition to the government not implementing proposals made regarding employment of ECDE teachers (Sessional Paper no.1 of 2005) which proposed that all ECDE teachers would be employed by the government by the year 2010 . This concurred with the study finding of Owiye (2010) which indicated that ECDE teacher salaries was poor and teachers lacked opportunities for professional development.

Further, 214(69.3\%) respondents agreed with the statement that there was lack of opportunities for professional development of pre-school teachers' due to inadequate funding, 69(22.3\%) respondents were in disagreement with the statement and 26(8.4\%) respondents were not decided on the statement. The responses showed that majority $(69.3 \%)$ of ECDE teachers and SMC chairpersons believed that ECDE teachers in Uasin-Gishu County lacked opportunities for professional development due to poor funding by the county government and the parents. This shows that professional training of ECDE teachers is an individual's initiative and is not provided for by the county governments and therefore teachers could be lacking some skills to manage the emerging trends influencing curriculum implementation and financial management issues in ECDE centres. World Bank Report (1998) reported that funds for training and equipment are limited were limited in most ECDE centres in Africa. However, Ijaiya (2001) revealed that with adequacy of resources in learning institutions, access to education can be enhanced while quality may be affected by limited funding. On the other hand, other nations that achieved the economic and social benefits associated with Early childhood education and have devoted greatly in it include Zambia, South Africa, Brazil, Niger and Ghana (Ramires, Paira \& Almeida, 2009).

Similarly, 260(84.1\%) participants were in disagreement with the statement that the provision of finances by the county government has enabled the acquisition of learning materials and resources in ECDE centres, 49(15.9\%) respondents agreed with the statement. It appeared therefore that majority $(84.1 \%)$ of the teachers and SMC 
chairpersons in Uasin Gishu County believed that the county government had not provided finances for acquisition of learning materials and resources in ECDE centres. Currently, the county governments subsidies salary for only one or two teachers but do not provide any other funding for acquisition of learning materials and resources such as play materials, teaching and learning aids. This implies that provision of teaching and learning resources in ECDE centres is majorly shouldered by parents and occasionally other education stakeholders. This supports MoE, (2005) directive that the ECDE parents were anticipated to offer financial support which is used for procurement of teaching and learning resources, payment of teachers' salaries, provision of physical facilities and supporting feeding programmes.

On the statement that the government has introduced grants to provide free meals to learners in ECDE centres to cater for the nutritional needs of disadvantaged learners, 219(70.9\%) participants were in disagreement with the view,77(24.9\%) respondents were in agreement with the view while 13(4.2\%) participants were not decided on the statement. From the responses, it can be deduced that majority (70.9\%) of the ECDE teachers and SMC chairpersons in Uasin-Gishu County believed that the government had not introduced grants to provide free meals to pre-schools learners so as to enhance the nutritional needs of disadvantaged learners. This is attributed to the fact that feeding programmes in ECDE centres depend on parents and local organizations of the ECDE teachers and SMCs and may not be in a position to sustain them due to limited finances. When this is the case, priorities for the most pressing needs like payment of teachers' salaries and payment of bills would be considered at the expense of feeding programmes. This compromises or stifles growth, reduces enrolment as many children are attracted to enroll through feeding programmes. This supports the findings of Sitati et al., (2014) which pointed out that most ECDE centres in Kenya had implemented the feeding program through parental and other stakeholder participations. However, this is contrary to the national strategy that has been introduced in Ghana by the government which aims at providing free meals to children in schools to improve the nutritional needs of disadvantaged children as noted by Kwadwo-Agyei, (2008).

Furthermore, 224(72.5\%) respondents agreed with the statement that payment of teachers' salaries has been hampered by the effect of Free Primary Education (FPE), 51(16.5\%) respondents were in disagreement with the view while 34(11.0\%) respondents were not decided on the view. From the results, it emerged that majority (72.5\%) of the respondents believed that payment of ECDE teachers' salaries has been hampered by the effect of Free Primary Education (FPE). This is due to the fact that the introduction of FPE by the government was implemented without putting into consideration the ECDE section. However, on their part parents believe that the government also caters for the ECDE sector making it difficult for the ECDE centres to raise adequate funds to pay teachers' salaries through school fees collections. This is consistent with World Bank Report (2010) which noted that financing mechanisms in early childhood education sector in Kenya was largely affected by Free Primary Education (FPE) program, unclear policy guidelines on management of ECDE education, lack of sufficient trained personnel, limited finances, poor or inadequate infrastructure to political interference.

\section{Correlation Coefficient between Co-ordination Strategies and Efficacy in the Administration of Finances in ECDE centres:-}

The hypothesis of this study stated that:

$\mathrm{HO}_{1}$ :-

There is no significant relationship between co-ordination strategies and its effects on efficacy in the administration of finances in public ECDE centres in Uasin-Gishu County. Pearson correlation analysis was used to test this hypothesis and the outcomes of analyzed data are shown in Table 3.

Table 3:- Relationship between Co-ordination Strategies and Efficacy in the Administration of Finances in ECDE centre

\begin{tabular}{|l|c|}
\hline \multirow{3}{*}{ Coordination } & Financial efficacies \\
\cline { 2 - 2 } & $\mathrm{r}=.638^{* * *}$ \\
\cline { 2 - 2 } & $\mathrm{p}=.000$ \\
\hline
\end{tabular}

**. Correlation is significant at the 0.01 level (2-tailed).

Table 3 shows a significant positive correlation $(r=.638 ; p=.000)$ between coordination strategies employed and financial management efficacy in public ECDE centres in Uasin-Gishu County. The null hypothesis which stated that: "there is no significant relationship between co-ordination strategies and efficacies in the administration of 
finances in public ECDE centres in Uasin-Gishu County" was therefore rejected and the alternate accepted showing that there is a statistically significant and positive relationship between coordination strategies and financial management efficacies. The positive correlation was contributed by the attempt of the school management to source for funds from parents and well-wishers to run ECDE programmes in addition to lobbying for payment of fees by parents and championing for support from ECDE sponsors (churches and host primary schools). It also emerged that management committees took the forefront to lead parents in supporting existing programmes in the various ECDE centres.

In this study, coordination therefore provides an organization the ability to integrate heterogeneous activities for achieving specific targets. It is also observed that coordination is acknowledged as an important aspect of organizational structure that includes the design of systems to ensure effective coordination, communication and integration of efforts across departments (Daft, 2010). Results indicated that most stakeholders have ceased supporting ECDE programme due to mistrust or lack of communication on financial performance and the only source being payment of fees by parents which sometimes delays. The auditor attributed the challenge to non-clarity of transactions, poor payment of fees, and incompetence of SMCs to handle finances, to the effects of FPE.

The QASO indicated that one or two programmes function may fluctuate due to limited finances. On the other hand, the teachers had not advanced their academic qualifications so as to improve in-services delivery and this was attributed to lack of finances to pay fees including non-sponsorship. It was also indicated that ECDE feeding programmes if well managed would always boost enrollment and provide the nutritional values required at that age (4-8 years).

The County Director also noted that most ECDE centres depend on fee payment from parents or sponsors, donations from other education stakeholders like NGOs and Churches. In addition, the county governments subsidize payment of one or two teachers' salaries per school besides infrastructure development (CIDP, 2013/2014).

Another study by Davis (2006), indicated that ECDE committee, parents and teacher consultations and collaborations in school resource mobilization and decision-making creates the climate for greatest fulfilment of the learners' potential to access the required learning resources which will enhance the value of education they will be exposed to. Further, involvement of other stakeholders, particularly teachers, in school decisions is considered to be a significant feature of educational management and can lead to the identification of necessary resources for teaching and learning in public ECDE schools. In an interview, the auditor cited poor performance on financial management by ECDE committee, that there is poor planning and utilization of resources in most public ECDE centers. It was cited that most centers receive and use finances as they come specifically for the most pressing needs.

\section{Conclusions and Recommendations:-}

The study found out that there was a statistically significant and positive relationship between coordination strategies and efficacy in the administration of finances in public ECDE centres in Uasin-Gishu County. The findings further indicated that infrastructural development funds for ECDE schools in the county are mainly from government and parents, that parents buy for their children school uniform and stationery, that pre-schools lacked basic physical infrastructure, like drinking water, toilets, buildings and classrooms and this was attributed to inadequate funding by the government, ECDE teachers' remunerations is poor, ECDE teachers lack opportunities for professional development due to poor funding by the county government and the parents, the county government has not provided finances for acquisition of learning materials and resources in ECDE centres, the government has not introduced grants for feeding programmes in pre-schools to enhance the nutritional requirements of underprivileged learners and finally payment of ECDE teachers' salaries has been hampered by the effect of Free Primary Education (FPE). It can therefore be concluded that coordination strategies employed are weak hence compromising on financial management efficacies in public ECDE centres in Uasin-Gishu County.

Results also indicated that coordination strategies employed in public ECDE centres are weak and need to be strengthened further by setting aside funds for capacity building and human resource development, including lobbying for stakeholders' support to fund ECDE programmes. Moreover, there is need for the government to extend FPE programmes to cover ECDE levels and increase funding to sustain various programmes in ECDE. 


\section{References:-}

1. Allis, R. P. M. (2004). Financial management: Ratio analysis zero to one million. New York: McGraw-Hill.

2. Ayot, H. O. \& Briggs, H. (1988). Economics of Education. Nairobi: Kijabe Printing Press.

3. Creswell, J. W. \& Plano-Clark, V. (2007). Designing and Conducting Mixed Methods Research. Thousand Oaks, CA.: Sage.

4. Cruickshank, V., Pedersen, S., Hill, A., \& Callingham, R. (2015). Construction and validation of a survey instrument to determine the gender-related challenges faced by pre-service male primary teachers. International Journal of Research \& Method in Education, 38(2), 184-199.

5. Daft, R. (2010). Organization Theory and Design (10th ed.). Ohio: South-Western Cengage Learning.

6. Elimu Yetu Coalition. (2014). Reform Agenda for Education Sector in Kenya: setting Beacons for, policy and Legislative framework. Nairobi, Kenya.

7. Getange, K.N, Onkeo, J.M. \& Orodho, A. J. (2014). Alternative sources of funding free day secondary education (FDSE) in public schools in Kisii central District, Kisii County, Kenya. International Organization of Scientific Research (IOSR) Journal of Dental and Medical Sciences (IOSR-JDMS) 13, (4), 14-23.

8. Hesse-Biber, S. N., \& Leavy, P. L. (2007). Feminist research practice: A primer. Thousand Oaks, CA: Sage.

9. Ijaiya, Y. (2001). From Quality Control to Quality Assessment: A panacea for Quality Education in Nigeria Schools in N.A. Nwagu, E.T. Ehiaetalor, M.A. Ogunu \& Mon Nwadiani (Eds). Current Issues in Educational Management in Nigeria. A publication of the Nigerian Association of Educational Administration and Planning.

10. Jane, J. M., Rotich, S.K. \& Kiprop, C (2014). Challenges facing school board of management in the implementation of the procurement policy in Kenya. Global Journal of Interdisciplinary Social Sciences, 3(3), 104-112.

11. Kasomo, D. (2001). Research Methods in Humanities and Education. Njoro, Egerton University Press.

12. Kibera, W. K \& Kimokoti, A. (2007). Fundamentals of Sociology of Education with Reference to Africa. Nairobi: University of Nairobi Press.

13. KIPPRA (2008). Public Expenditure Tracking of Secondary Education Bursary Fund in Nairobi Province, Kenya at http://www.ipar.or.ke

14. Kothari, C. R., (2008). Research Methodology: Methods and Techniques (2 ${ }^{\text {nd }}$ Ed).Age, New Delhi, International publishers.

15. Krejcie, R. V, \& Morgan, D. W. (1970). Determining sample size for Research Activities. Educational \& Psychological measurement,30, (1) 607-610).

16. Kwadwo-Agyei, D. (2008). Over 447000 pupils benefiting from school feeding Programme. Accra, Ghana; News Agency.

17. Meyer, J. P., Becker, T. E. \& Vandenberghe, C. (2004). Employee commitment and motivation: A conceptual analysis and integrative model. Journal of Applied Psychology, 89, p. 991-1007.

18. Ministry of Education Science and Technology, (2005). Policy Review Report: Early Childhood Care and Education in Kenya. The Section for Early Childhood and Inclusive Education, Education Sector. Paris: UNESCO.

19. Mogire, R. N (2013). Financial strategies used by secondary school principals in addressing budgetary deficit in Nakuru District, Nakuru County, Kenya. Unpublished MED thesis, University of Nairobi.

20. Mohammad, S. (2011). Status of Missing Physical Facilities in Government Schools in Punjab. Unpublished Report.

21. Okumu, R (2014). Management of Free Primary Education Funds in Kenya. LAP LAMBERT Academic Publishing, London.

22. Onen, D. \& Oso, W. Y. (2005). Writing research proposal. Kisumu: Options printers

23. Owiye, J. (2010). Management of resources in ECDE centres and its implications on quality of ECDE in Bungoma East District. Unpublished M.Ed thesis. Masinde Muliro University of Science and Technology.

24. Ramires, V. R., Paira, M.G.G. \& Almeida, L. (2009). Early Childhood Care and Education: Worldwide Challenges and Progresses, http://www.tc.edu/ cic/issues/ 11.00/PDFs/11 completeissue.pdf.

25. Sitati, E. M., Bota K. \& Ndirangu, M. (2014). Financing mechanisms in early childhood education in Kenya: A case of Kakamega County. Journal of Education Research and Behavioral Sciences 3(8). 273-286

26. UNESCO (2005). The Selection for Early Childhood and Inclusive Education. Paris UNESCO Publishing

27. WHO (2013). Meeting report: nurturing human capital child development WHO publication

28. WHO (2014). Global health observatory. www, who.int/gho/child-health/ mortality/ mortalityudenrfive-text/en/

29. World Bank (1998). Project Appraisal Document, Philippines Early Childhood Development project. World Bank, Washington D.C.

30. World Health Organisation statistical information System: WHOSIS (2008). http://apps.who.int/whosis/database/core/core_select_process.cfm?countries $1 / 4 \mathrm{ken} \%$ indicators $1 / 4$ child_mort. Obtained 26th October 2017. 